\title{
Determinants and spatial dependence of innovation in Brazilian regions: evidence from a Spatial Tobit Model
}

Determinantes e dependência espacial da inovação nas regiões brasileiras: evidências a partir de um Modelo Tobit Espacial

\author{
Veneziano de Castro Araújo (1) \\ Renato Garcia (2) \\ (1) Universidade Federal de São Paulo \\ (2) Universidade Estadual de Campinas
}

\section{Abstract}

This paper analyses the spatial patterns and spatial interdependencies of innovation and the role that local determinants of innovation play in Brazilian micro-regions. Specifically, it evaluates how local firms' R\&D, regional academic research, agglomeration level and local industrial specialization or diversification affect regional innovation. To analyse these factors, an empirical model based on the Knowledge Production Function (KPF) is estimated using a Spatial Autoregressive Tobit (SAR-Tobit) with Brazilian patent data. The results indicate that higher levels of regional industrial R\&D imply greater innovation and that greater university research at a regional level positively impacts industrial innovation. Moreover, agglomerated and diverse regions present better innovative performance. Regarding spatial dynamics, the proximity of the most innovative microregions positively affects local innovation, which shows the existence of interregional knowledge spillovers that are associated with innovative activities.

\section{Keywords}

regional innovation, patents, Brazil, spatial tobit.

JEL Codes O18, O33, R11.

\section{Resumo}

Este artigo busca analisar os determinantes da inovação, os padrões espaciais e a dependência espacial da inovação nas microrregiões brasileiras. Em concreto, ele avalia como o P\&D das empresas locais, a pesquisa acadêmica regional, o nivel de aglomeração e a especialização ou diversificação industrial da localidade afetam a inovação regional. Para analisar esses fatores, foi estimado um modelo empirico baseado na Função de Produção do Conhecimento (FPC) com dados de patente no Brasil por um Tobit Espacial Autoregressivo (SAR-Tobit). Os resultados indicam que niveis mais elevados de P\&D Industrial Regional implicam em maior inovação e que maiores niveis de pesquisa universitária impactam positivamente a inovação na região. Além disso, regiões mais aglomeradas e diversificadas apresentam melhor desempenho inovador. Em relação à dinâmica espacial, a proximidade das microrregiões mais inovadoras afeta positivamente a inovação local, o que mostra a existência de spillovers de conhecimento inter-regionais associados inovação medida por patentes.

\section{Palavras-chave}

inovação regional, patentes, Brasil, tobit espacial.

Códigos JEL O18, O33, R11. 


\section{Introduction}

The location of innovation and the role of proximity in knowledge flows have received increasing attention in the regional science and economic geography literatures. Assessing innovation from a regional perspective assumes that innovative activities are influenced by the local context; in certain circumstances, location can enhance or limit firms' innovation. This phenomenon occurs because the knowledge and skills necessary for innovation become more easily accessible in locations where more accumulated knowledge are concentrated and a high number of qualified professionals frequently interact.

Geographical proximity among agents can facilitate the assimilation of complex knowledge used in innovative activities. In this way, it is important to analyse the role of local knowledge spillovers and the local context as drivers of regional innovation. Through knowledge spillovers, knowledge created and accumulated due research activities in firms and universities may benefit the innovative activities of nearby firms. These interregional spillovers are important determinants of local innovation and can be evaluated with different spatial econometric specifications (Greunz, 2003; Fischer and Varga, 2003; Crescenzi et al., 2007; Autant-Bernard and LeSage, 2011).

Innovation activity is not evenly distributed geographically; rather it is concentrated in certain regions. Several empirical studies show that innovation is even more spatially concentrated than manufacturing (Audretsch and Feldman, 1996; Crescenzi et al., 2007; Corsatea and Jayet, 2014) and that denser urban areas are more innovative (Carlino et al., 2007; Carlino and Kerr, 2015). Another point that is often made in the literature and that demands further analysis is how regional sectoral specialization or diversification generates different advantages (Marshallian or Jacobian ones) and how it propagates by the means of spatial spillovers in innovation (Beaudry and Schiffauerova, 2009; De Groot et al., 2016). In spite of the growing concern regarding the relationship between geography and innovation, there is a lack of empirical evidence based on large-scale data for developing countries (Crescenzi et al., 2012).

This paper contributes to the literature by presenting new empirical evidence on this subject and analysing the relation of innovation and agglomeration and regional specialization or diversification. Additionally, it contributes by performing an empirical analysis using data from Brazil, 
which allows a deeper understanding of the determinants of innovation in the context of developing countries as a way to enable technological latecomers to catch up (Ying, 2008). The empirical model is based on the knowledge production function (KPF) and was estimated by a Spatial Autoregressive Tobit.

The remainder of the paper introduces a literature review about regional determinants of innovation (Sect. 2) and presents an exploratory Spatial Data Analysis that confirms the spatial concentration of innovation in Brazil - mainly in the South-Southeast regions - which reinforces the relevance of a spatial econometric approach (Sect. 3). Then, the model adopted and its variables are described with several methodological remarks (Sect. 4) and the estimation results are analysed and checked for robustness and alternative specifications (Sect. 5). Finally, concluding remarks are presented (Sect. 6).

\section{Regional determinants of innovation}

Innovation does not occur in the same manner in different locations. Remarkably, it depends on firms' local environment because firms not only use internal resources to innovate but also employ external local factors to foster innovation. Knowledge creation and diffusion are strongly related to space. Knowledge is embodied in academic and industrial researchers and the tacit dimension of knowledge attests that knowledge exchange occurs with higher efficiency and lower costs through face-to-face contacts (Storper and Venables, 2004). Furthermore, when a given region possesses a high concentration of highly qualified professionals, a rich and complex local knowledge base is created, which intensifies local knowledge spillovers and benefits firm innovation. Innovation is facilitated by interaction, cooperation and a collective learning process (Capello and Lenzi, 2013). Geographical proximity is frequently associated to other types of proximity, such as cultural, social or technological proximity, which strengthen these benefits (Paci et al., 2014). Regions with an accumulated knowledge and skill base will perceive advantages in innovation due to better use or access to specific and complex knowledge related to industrial or academic research.

Local industrial and academic R\&D activities play a crucial role in regional innovation, as the seminal study of Jaffe (1989) has shown. There 
is an extremely straightforward reasoning for this finding: as the resources applied to innovative activities (studies, laboratories, funds, etc.) increase, local innovation increases. A region with a large number of researchers can provide more efficient assets related to innovation, such as specialized services or skilled professionals, which implies more and better opportunities for technology transfers or R\&D cooperation. This environment also affords the attraction of new qualified workers and improves the absorptive capacity of firms.

In the case of academic $R \& D$, the new knowledge generated by universities and research centres is utilized by companies for various mechanisms, intentional or not, such as hiring qualified researchers from universities' research groups, generating new spinoff firms, or creating formal collaborative contracts.

Geographical proximity plays a crucial role in fostering innovation. Innovative processes in a firm in a given location can benefit from nearby firms and university research in the same region due to spatial knowledge spillover mechanisms (Duranton and Puga, 2000; Crescenzi et al., 2007). This physical proximity advantage also extends to neighbouring locations, so regions that are close to highly innovative regions also experience benefits. Instead, it is more difficult for isolated individual firms to benefit from the innovation of the most geographically distant.

According to this view, being located in a region with a high number of innovative firms or near a region with greater innovation allows the firm to exploit important benefits from spatial intra and interregional knowledge spillovers in its innovative activities. In fact, evidence of both types of spatial spillovers are present in the literature (Autant-Bernard and LeSage, 2011) and several studies show that innovative activities in a certain locality can benefit the entire neighbouring region and vice versa (Fischer and Varga, 2003; Moreno et al., 2005, Crescenzi et al., 2007).

In addition, other studies on regional innovation have evaluated the role of agglomeration in innovation showing that spatial agglomeration presents clear advantages for innovation by allowing external scale economies and more interactions between local agents (Moreno et al., 2005; Carlino et al, 2007; Carlino and Kerr, 2015).

Regarding local sectoral specialization, many studies have found evidence that regions specialized in a given economic activity innovate more (CabrerBorrás and Serrano-Domingo, 2007, Henderson 1997, 2003). This evidence 
is theoretically linked to Marshallian externalities that indicate that regional specialization implies a great number of specialized suppliers, a vast pool of skilled workers and a larger stock of industry-specific knowledge that flows better locally. Specialization reduces transaction costs and facilitates communication-intensifying knowledge spillovers. Together these factors contribute to more innovation among local enterprises in that industry.

In contrast, other studies present evidence that the diversification of industrial activities is the most beneficial for innovation in regions (Feldman and Audretsch, 1999 and Fritsch and Slavtchev, 2007). These activities are closely related to the Jacobian advantage, which posits that knowledge transfers between different sectors allow a greater number of radical innovations through what the author calls 'cross fertilization'. It occurs due to the higher complementarities of firms' knowledge bases that generate synergic advantages in innovation. Knowledge creation and learning often depend on a combination of diverse, complementary capabilities among heterogeneous agents (Capello and Lenzi, 2013). This argument is supported by a higher number of new firms and industries in more diversified cities (Duranton and Puga, 2001).

Despite the vast number of works related to this topic, the debate on whether specialized or diversified regions are the most important for innovation remains open. Comparing these results is a complex task because of their different specialization-diversification indicators, sector composition or geographical levels of analysis (Beaudry and Shiffareova; 2009).

As shown, while the panorama of local innovation is extremely broad and diverse, many questions remain open and require further empirical evidence. Therefore, this paper attempts to conduct a deeper analysis of the role of various factors in local innovation and assess their spatial interregional spillover effects. To accomplish this, a Brazilian regional dataset of patents is used. Additionally, a Spatial Autoregressive Tobit model is used to capture the regional spillover effects on innovation and explicitly control for regions that do not produce any patents.

\section{Regional distribution of innovative activities in Brazil}

Innovation in Brazil is concentrated in South and Southeast regions of Brazil (Albuquerque et al., 2009; Gonçalves and Almeida, 2009). The population 
density, GDP per capita and workforce education levels in these regions are higher than the national average. Although Brazil is a developing country, this scenario is quite similar to that in developed countries such as France (Corsatea and Jayet, 2014) and the United States (Carlino et al., 2007).

Brazilian firms belong primarily to low and medium technology industrial sectors (Chaves et al., 2016; Fornari et al., 2014), and many of their innovative activities are supported directly or indirectly by universities that play a fundamental role in fostering innovation in firms through formal or informal channels (Suzigan et al., 2009; Fernandes et al., 2010; Chaves et al., 2016).

The number of studies analysing innovation in Brazil from a regional perspective has been increasing. Some of them focus on the regional distribution of innovation in Brazil (Simões et al., 2002; Gonçalves, 2007) or in a specific state (Montenegro et al., 2011). Although studies show some evidence of deconcentration (Oliveira et al., 2016), innovation remains strongly concentrated in the South-Southeast regions. Previous studies have also evaluated the innovative potential of these regions (Sobrinho and Azzoni, 2017) or regional differences in technological subdomains (Rodriguez and Gonçalves, 2017).

However, few studies have empirically analysed the determinants of regional innovation in Brazil (Gonçalves and Almeida, 2009, Freitas et al., 2010, Gonçalves and Fajardo, 2011, Oliveira et al. 2016). Using per capita patents in the micro-regions, Gonçalves and Almeida (2009) found that regional structure (local R\&D, agglomeration, etc.) and spatial spillover have an important role in regional innovation. Proximity is also a key point in Gonçalves and Fajardo's (2011) study; they found that not only geographic distance but also technological distance (measured by the technological classes of patents) explains a relevant part of knowledge spillovers in Brazilian mesoregions. Finally, Freitas et al. (2010) and Oliveira et al. (2016) evaluated the pace and determinants of convergence in patenting in Brazilian regions.

Given the small number of articles on the subject in Brazil, two points must be better explored and represent the contributions of this article. First, there are several regions with few or no patents. Only two previous studies have highlighted this difficulty and proposed approaches. Oliveira et al. (2016) opted to exclude regions without patents, while Gonçalves and Fajardo (2011) adopted a more aggregated regional level (mesoregions). 
However, these strategies impose limitations to the results, and ignoring the presence of large numbers of zeros naturally leads to the underestimation of the coefficients (LeSage and Pace, 2009).

Second, only Gonçalves and Almeida (2009) analysed the effect of relative productive specialization and diversification on innovation in the regions. Therefore, it is still necessary to better evaluate the circumstances surrounding the specialization or diversification of the regional impact on innovation, including a way to better target public policies.

In this sense, this paper seeks to deepen the analysis of the determinants of regional innovation in Brazil with a special focus on the regional productive structure while also dealing more appropriately with the regions without patents. The Spatial Tobit model is adopted as the econometric approach because it more appropriately deals with regions without patents.

\section{Methodology and model specification}

The role of geography in innovation was first shown by Jaffe (1989), who applied an adapted version of Griliches' (1979) KPF to geographical units. Later, this set of econometric models was improved with spatial econometrics tools and more specific data that were more spatially disaggregated (Acs et al., 1994; Anselin et al., 1997; Crescenzi et al., 2007; Fritsch and Slavtchev, 2007).

Patents granted or patent applications in each location were largely used as a proxy for local innovation output. Patents have advantages as indicators of innovation because they are directly related to the inventive process, depend on objective and stable criteria and are widely available and detailed (Griliches, 1990). However, Nagaoka et al. (2010) recalled that there is no perfect alignment between patents and innovation. This implies some limitations, such as the underestimation of the inventive process, the failure to consider the economic value of the invention, and the fact that a technology can be protected by more than one patent. In this context, the wide prevalence of patents as an indicator of innovation in empirical work testifies that the benefits far outweigh the shortcomings, although it is necessary to adopt controls to guarantee good empirical results, such as the sharing of the manufacturing sector in the region of industries especially prone to patents (Gonçalves and Almeida, 2009 Gonçalves et al., 
2016). Recent studies have also used patents as the standard proxy for innovation (Crescenzi et al., 2007; Fritsch and Slavtchev, 2007, Corsatea and Jayet, 2014).

In this paper, the model is based on the KPF, with spatial elements and additional controls. The general specification of the function as follows (Equation 1):

$$
I_{i t}=f\left(R D_{i, t-1}, E_{i t}, \text { Controls }\right)
$$

where $I_{i t}$ is the innovation performance of region $i$ measured by the number of patents filed in the region; $R D_{i t-1}$ is the $\mathrm{R} \& \mathrm{D}$ expenditure from firms and universities in region $i$ in the preceding period; and $E_{i t}$ represents the characteristics of the local productive structure (level of agglomeration and specialization of local economy). This time-lag structure allows us to take into account the delay between research and its results are sufficiently mature in terms of formalization to file a patent as adopted in other studies (Corsatea and Jayet, 2014; Paci et al., 2014).

Before detailing the model, it is important to note some additional methodological remarks. First, for the geographical level of aggregation, this study adopted the micro-regional level, which is similar to EU NUTS-3. We verified the regional distribution of innovative activities performed with the test of autocorrelation of patents per capita in Brazilian microregions between 2001 and 2005 .

This test rejects the null hypothesis of no spatial autocorrelation (Annex A.1). Additionally, the positive result of the Moran index indicates that more innovative regions are spatially clustered and, consequently, that regions with lower innovation levels are clustered, generating a spatially heterogeneous distribution of innovation in Brazil. The Local Indicator of Spatial Autocorrelation (LISA) map shows a high concentration of highly innovative regions in the southern regions of Brazil, converging to the spatial concentration of manufacturing.

In addition, large geographical gaps can also be noted, because 229 of the 558 micro-regions produced no patents in the 2001-2005 period (Figure 2).

Most of these measurement issues can be mitigated with an appropriated cohort, but Brazil does not have an official statistical selection of targeted industrial and urban centres, such as the Metropolitan Statistical Areas (MSAs) in the United States. 
Figure 1 LISA Map - High-high and low-low patents per 100,000 inhabitants in Brazilian micro-regions, 2001-2005
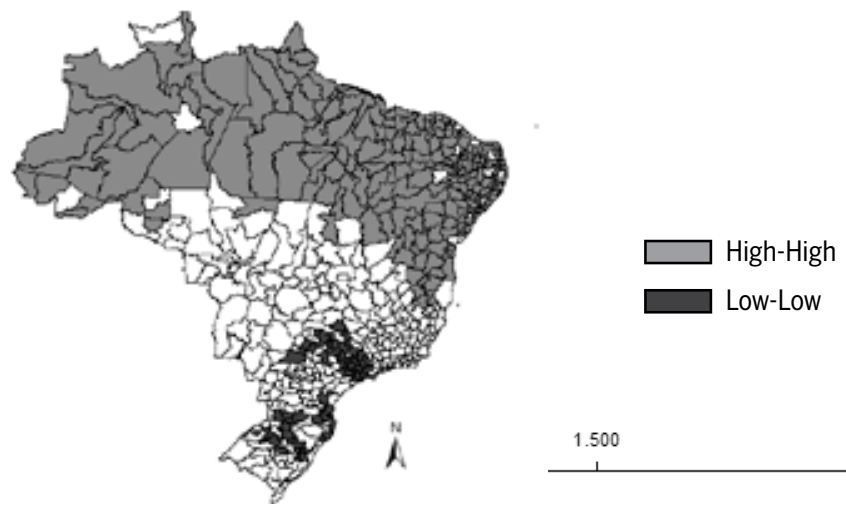

Source: Author' own elaboration.

Figure 2 Patents per 100,000 inhabitants in Brazilian micro-regions, 2001-2005



Patents $/ 100.000$ inhab.

Source: Author' own elaboration.

To address this issue, this study used a Spatial Tobit Model that can address a high proportion of zero-patent regions because it treats patent statistics as a measure censored to zero and modelled by a Spatial Tobit. LeSage and Pace (2009) report that this model deals with observations that result in truncated distributions as the patent statistics that are censored to zero. The latent regression in the spatial model is similar to the case of the Tobit, and the estimation technique consists of producing a latent dependent variable for censored observations using Markovian-Chain Monte 
Carlo simulation. This model allows the explicit control of regions that do not produce any patents, as reported in previous studies (Autant-Bernard and LeSage, 2011; Kang and Dall'erba, 2015).

Regarding spatial dependence, a Spatial Autoregressive (SAR) model was used because it allows the analysis of spatial dynamics and the effects of interregional innovation spillovers in spatial autoregressive terms ${ }^{1}$. The complete model is outlined as follows, and the descriptions of variables are presented in Table 1.

$$
\begin{aligned}
& P_{\text {atPC }}=\text { WPatPC }_{i, t}+R \& \operatorname{DInd}_{i, t-1}+R \& D \text { Univ }_{i, t-1}+\text { Agglom }+ \\
& +K I+\text { ShrInd }+ \text { Sec }+ \text { Metro }+ \text { NNE }
\end{aligned}
$$

\begin{tabular}{|c|c|}
\hline Variable & Description \\
\hline PatPC & $\begin{array}{l}\text { Patents filed in } 2004 \text { or } 2005 \text { per 100,000 inhabitants in the regions. Source: Brazilian } \\
\text { Patent Office }\end{array}$ \\
\hline R\&DInd & $\begin{array}{l}\text { Industrial R\&D of a region; percentage of employees in manufacturing and mining } \\
\text { working and acting in R\&D activities per total employees. Source: Ministry of Labor } \\
2003 / 2004 \text {. }\end{array}$ \\
\hline R\&DUniv & $\begin{array}{l}\text { Academic R\&D of a region, obtained by principal component analysis of RDU_prof, and } \\
\text { RDU stu (listed below); own elaboration }\end{array}$ \\
\hline$K I$ & $\begin{array}{l}\text { Krugman Index of specialization-diversification }{ }^{2} \text {, elaborated with data from the Minis- } \\
\text { try of Labor, } 2004 / 2005\end{array}$ \\
\hline Agglom & Population density of micro-regions; source: Brazilian Statistical Bureau \\
\hline Shrlnd & $\begin{array}{l}\text { Share of employment on manufacturing and mining or the share of the active popula- } \\
\text { tion; source: Ministry of Labor, } 2004 / 2005\end{array}$ \\
\hline $\operatorname{Sec}$ & Share of top 9 sectors in local employment; source: Ministry of Labor, 2004/2005 \\
\hline NNE & Dummy for the North, Northeast and Centre-West; own elaboration \\
\hline Metro & Dummy for metropolitan regions; own elaboration \\
\hline$R D U \_p r o f$ & $\begin{array}{l}\text { Number of university professors with full dedication per 10,000 inhabitants; source: } \\
\text { Brazilian Ministry of Education, 2003/2004 }\end{array}$ \\
\hline RDU_stu & $\begin{array}{l}\text { Number of students in master's, doctoral or post-doctoral programmes per 10,000 } \\
\text { inhabitants; source: Brazilian Ministry of Education, 2003/2004 }\end{array}$ \\
\hline
\end{tabular}

Table 1 Description of Variables

Source: Author' own elaboration.?

1 This specification provides an adequate specification of externalities in diffusion process of innovation Paci et al. (2014).

2 Following Crescenzi et al. (2007), the Krugman index measures local employment specialization by calculating a) for each region, the share of industry $k$ in the region's total em- 
- Local Innovation (PatPC). The dependent variable is patent applications per capita for each region, a proxy for local innovation (Moreno et al., 2005; Crescenzi et al 2007; Autant-Bernard and LeSage, 2011; Kang and Dall'erba 2014; Corsatea and Jayet, 2014; Paci et al., 2014). Patent grants often take several years to be defined, and the number of years may vary considerably between technological classes; thus, the application date is more stable and closer to the time at which knowledge is created (Kang and Dall'erba, 2014). Locational information on patent assignees were obtained and aggregated at the micro-regional level.

- Spatially Lagged Local Innovation (WPatPC). The autoregressive term was included in the model in order to evaluate the role of spatial spillovers in innovation to neighbours. A standard spatial weight matrix with a knearest matrix for 15 neighbours was used. Additional estimations were made with another spatial weight matrix as a robustness check.

- Industrial R\&D Expenditures (R\&DInd). The proxy for industrial R\&D expenditures at the regional level is related to human capital: the share of workers occupied in $\mathrm{R} \& \mathrm{D}$. The source is the Brazilian Ministry of Labour. This proxy is used because of the lack of data on $R \& D$ expenditures at the firm level. Previous studies include either industrial and academic $R \& D$ expenditures or just industrial R\&D (Crescenzi et. al., 2007). In this paper, the option was to include industrial and academic R\&D expenditures separately to measure their individual contributions to local innovation (Fritsch and Slavtchev, 2007; Kang and Dall'Erba, 2015).

- University R\&D Expenditures (R\&DUniv). Data on the academic expenditures of $R \& D$ are not available in Brazil. Thus, to measure academic $R \& D$, two different proxies are chosen. The first is the share of full-time university professors at the regional level, and the second is the number of graduate students applying to master's, doctoral and post-doctoral degrees. However, both proxies are imperfect because university professors may be dedicated only to teaching activities and graduate students may be employed in other activities not directly related to research. To limit these imperfections, these two variables were combined using principal component analysis, generating a new variable corresponding to the first component, labelled R\&DUniv. This single component cor-

ployment: $\left.v_{i}^{k}, b\right)$ the share of the same industry employment of all other regions $v_{i}^{-k}$ and; c) the absolute values of the difference between these shares, added over all industries: $K_{i}=\sum_{k} a b s\left(v_{i}^{k}-v_{i}^{-k}\right)$. 
responds to more than $80 \%$ of the explanatory power of both variables (Appendix A2).

- Indicator of specialization and diversification - Krugman Index (KI). In order to assess whether more specialized or diversified regions are more innovative, the Krugman index was used as a measure for the region's industrial structure (Crescenzi et al., 2007). The Krugman index varies from 0 to 2: most specialized regions assume values near 2 and the most diversified regions close to 0 . The index uses the number of employees in the manufacturing industry (at 2-digit level).

- Agglomeration (Agglom). Previous studies show that local innovation is frequently related to agglomerative advantages (Moreno et al., 2005). Therefore, denser regions tend to demonstrate higher innovative performance. In this way, an additional variable for the population density using the population census was introduced to the model.

- Controls. Four controls were included: first, the share of employment in manufacturing and mining or the share of the active population (ShrInd) (Carlino et al., 2007; Gonçalves and Almeida, 2009); second, the presence of certain industries is more prone to patents (Sec); third, dummies for the North, Northeast and Centre-West regions $(\mathrm{N})$; and fourth, dummies for Brazilian metropolitan regions (Metro).

\section{Results}

Three versions of the model were estimated using 2 years of pooled data (2004 and 2005) with a total sample size of 1,116 observations (558 microregions $\mathrm{x} 2$ years). The first version is an OLS (model 1) that includes all the variables but without spatial factors. The second estimated model is an SAR model (2) that includes the autoregressive term for patents. Finally, the third model is the SAR-Tobit model (3, Table 2$)$. The results were mainly the same.

Both Industrial (R\&DInd) and University (R\&DUniv) R\&D exhibit significant and positive coefficients, as expected, which means that patents at the local level grow when local companies' and universities' R\&D increase. Previous empirical studies that use similar specifications found that both local industrial and academic $\mathrm{R} \& \mathrm{D}$ are local determinants of innovation (Fritsch and Slavtchev, 2010; Kang and Dall'erba, 2015). 
Table 2 Results of regression- Patents per capita (log)

\begin{tabular}{|c|c|c|c|}
\hline & (1) OLS & (2) SAR & (3) SAR-Tobit \\
\hline WPatPC & - & $\begin{array}{r}0.52^{* * *} \\
{[105.979]}\end{array}$ & $\begin{array}{r}0.295^{* * *} \\
{[5.258]}\end{array}$ \\
\hline R\&DInd & $\begin{array}{r}0.138^{* * * *} \\
{[6.25]}\end{array}$ & $\begin{array}{r}0.118^{* * * *} \\
{[5.764]}\end{array}$ & $\begin{array}{r}0.144^{* * *} \\
{[3.991]}\end{array}$ \\
\hline R\&DUniv & $\begin{array}{r}0.432 * * * \\
{[8.477]}\end{array}$ & $\begin{array}{r}0.401^{* * *} \\
{[8.477]}\end{array}$ & $\begin{array}{r}0.477^{* * *} \\
{[6.298]}\end{array}$ \\
\hline Agglom & $\begin{array}{c}0.123^{* *} \\
{[2.781]}\end{array}$ & $\begin{array}{r}-0.008 \\
{[-0.194]}\end{array}$ & $\begin{array}{r}0.226^{* *} \\
{[2.631]}\end{array}$ \\
\hline$K I$ & $\begin{array}{l}-0.321^{*} \\
{[-2.09]}\end{array}$ & $\begin{array}{r}-0.569 * * * \\
{[-3.993]}\end{array}$ & $\begin{array}{r}-3.082^{* * *} \\
{[-9.911]}\end{array}$ \\
\hline Shrlnd & $\begin{array}{c}5.993 * * * \\
{[10.906]}\end{array}$ & $\begin{array}{r}3.941^{* * *} \\
{[7.737]}\end{array}$ & $\begin{array}{r}9.531^{* * *} \\
{[9.265]}\end{array}$ \\
\hline $\mathrm{Sec}$ & $\begin{array}{r}2.899 * * * \\
{[7.05]}\end{array}$ & $\begin{array}{r}2.193 * * * \\
{[5.749]}\end{array}$ & $\begin{array}{r}3.498^{* * * *} \\
{[4.701]}\end{array}$ \\
\hline Metro & $\begin{array}{r}2.214^{* * * *} \\
{[6.125]}\end{array}$ & $\begin{array}{r}2.494^{* * *} \\
{[7.438]}\end{array}$ & $\begin{array}{r}2.551^{* * * *} \\
{[4.547]}\end{array}$ \\
\hline NNE & $\begin{array}{r}-0.922 * * * \\
{[-5.737]}\end{array}$ & $\begin{array}{r}-0.004 \\
{[-0.027]}\end{array}$ & $\begin{array}{l}-1.152^{* *} \\
{[-3.455]}\end{array}$ \\
\hline $\operatorname{Adj}-R^{2}$ & 0.4664 & 0.4899 & - \\
\hline$L M-S A R$ & $180.48^{* * *}$ & - & - \\
\hline
\end{tabular}

Notes: ${ }^{* *} p<0.1 \%$; ${ }^{* *} p<1 \% ;{ }^{*} p<5 \%$; $t$-stat in brackets.

Regarding the local industrial structure, the Krugman index (KI) coefficient is negative and significant. KI takes higher values in specialized regions; therefore, as regions become more diversified, their innovative performance improves. This evidence shows the importance of local benefits of diversification for local innovation, in line with previous studies (Greunz, 2003, Fritsch and Slavtchev, 2007; Corsatea and Jayet, 2014). Additionally, population density is positively correlated with innovation, indicating that denser cities are more innovative. This result also confirms previous studies on the U.S. (Carlino et al., 2007; Carlino \& Kerr, 2015), Europe (Moreno et al., 2005) and Brazil (Goncalves and Almeida, 2009).

From a spatial perspective, the positive and highly significant parameter of the spatially lagged dependent variable (WPatPC) suggests that knowledge flows between spatially proximate regions are important sources of innovation. Therefore, more innovative neighbours implies more innova- 
tion in the region, probably through spatially mediated spillovers. The positive and significant coefficient of the spatial lagged dependent variable confirms Gonçalves and Almeida's (2009) previous results but better deals with the reality that some regions present zero patents in some years with correction of the potential downward bias in samples censored to zero (LeSage and Pace, 2009).

All controls present the expected sign and are significant. Metropolitan regions, with higher shares of industrial activities and specific sectors with greater propensities to patent, present higher levels of patents per inhabitant - similar to previous studies (Moreno et al., 2005; Carlino et al., 2007; Gonçalves and Almeida, 2009). Finally, micro-regions not located in the South and Southeast present lower levels of patents per capita confirming the importance of the regional heterogeneity of innovation in Brazil with a lower innovation pattern outside the main industrial areas.

In order to ensure the accuracy of the main results, other model specifications were tested. To ensure that the weight matrix specifications are appropriate and the results are not particularly sensitive to the form adopted in the weight matrix, the original model was estimated again with alternative spatial weight matrices ${ }^{3}$. The results, presented in the Annex, remain the same, even in terms of the coefficients (original signal and significance level) and the magnitude of the coefficients is quite similar (LeSage and Pace, 2014).

Alternative specifications were also tested with changes in the dependent variable (models I and II). First, following Ying (2008), we used a more restrictive proxy for innovation. The Brazilian Patent Office categorizes patents as invention patents or design/utility models. We replaced total patents per capita by the number of invention patents per capita because this nomenclature represents higher-quality intellectual property. Second, a model with total patents excluding university patents. Although the total number of university patents is of little significance, it is important to check that the positive impact of R\&D University on the total level of patent remains after this exclusion (the new variables are listed in Table A.4 in the Annex).

Regressions with alternative specifications that use only invention patents (PatInvPC - Model I) and without university patents (PatnUnivPC -

3 The alternative weight matrices are: $k$-nearest with the 20 nearest neighbors (instead of the 15 included in the main model), the inverse of distance and Queen. According to LeSage and Pace (2014), little change in the results is expected, even with such different matrices. 
Model II) present the same results as the original model, showing that the empirical results are robust to more specific innovation types and when university patents are removed.

Table 3 Regression results - Patents per capita (log) - Alternative variables and cohort

\begin{tabular}{|c|c|c|c|c|c|c|}
\hline & $\begin{array}{r}\text { PatInvPC } \\
\text { (I) }\end{array}$ & $\begin{array}{r}\text { PatnUnivPC } \\
\text { (II) }\end{array}$ & $\begin{array}{r}\text { HH } \\
\text { (III) }\end{array}$ & $\begin{array}{r}\text { Professors } \\
\text { (IV) }\end{array}$ & $\begin{array}{r}\text { S-SE } \\
\text { (V) }\end{array}$ & $\begin{array}{r}2001-2005 \\
(\mathrm{VI})\end{array}$ \\
\hline WPatPC $_{t}$ & $\begin{array}{l}0.180^{* *} \\
{[2.856]}\end{array}$ & $\begin{array}{r}0.301^{* * *} \\
{[5.480]}\end{array}$ & $\begin{array}{r}0.333^{* * *} \\
{[6.142]}\end{array}$ & $\begin{array}{r}0.275^{* * *} \\
{[4.940]}\end{array}$ & $\begin{array}{r}0.298^{* * * *} \\
{[4.055]}\end{array}$ & $\begin{array}{r}0.258^{* * *} \\
{[6.992]}\end{array}$ \\
\hline$R \& D / n d_{t-1}$ & $\begin{array}{r}0.099^{* * * *} \\
{[4.407]}\end{array}$ & $\begin{array}{r}0.136^{* * *} \\
{[3.698]}\end{array}$ & $\begin{array}{c}0.114^{* *} \\
{[3.111]}\end{array}$ & $\begin{array}{r}0.137^{* * *} \\
{[3.707]}\end{array}$ & $\begin{array}{l}0.107^{* *} \\
{[2.742]}\end{array}$ & - \\
\hline Eng & - & - & - & - & - & $\begin{array}{l}0.009^{* *} \\
{[3.000]}\end{array}$ \\
\hline$R \& D U n i v_{t-1}$ & $\begin{array}{r}0.384^{* * * *} \\
{[7.765]}\end{array}$ & $\begin{array}{r}0.373^{* * *} \\
{[4.845]}\end{array}$ & $\begin{array}{r}0.517^{* * * *} \\
{[6.669]}\end{array}$ & - & $\begin{array}{r}0.440^{* * *} \\
{[5.528]}\end{array}$ & $\begin{array}{r}0.366^{* * *} \\
{[7.618]}\end{array}$ \\
\hline Prof & - & - & - & $\begin{array}{r}0.074^{* * *} \\
{[5.425]}\end{array}$ & - & - \\
\hline Agglom & $\begin{array}{l}0.154^{* *} \\
{[2.793]}\end{array}$ & $\begin{array}{r}0.246^{* *} \\
{[2.921]}\end{array}$ & $\begin{array}{r}0.03 \\
{[0.358]}\end{array}$ & $\begin{array}{l}0.257^{* *} \\
{[3.044]}\end{array}$ & $\begin{array}{r}0.249 \\
{[1.829]}\end{array}$ & $\begin{array}{r}0.283^{* * *} \\
{[5.400]}\end{array}$ \\
\hline$I E D(K I)$ & $\begin{array}{r}-2.042^{* * *} \\
{[-9.818]} \\
\end{array}$ & $\begin{array}{r}-3.150^{* * * *} \\
{[-10.120]} \\
\end{array}$ & - & $\begin{array}{c}-3.197^{* * *} \\
{[-10.261]} \\
\end{array}$ & $\begin{array}{r}-3.436^{* * *} \\
{[-8.309]} \\
\end{array}$ & $\begin{array}{c}-3.131^{* * *} \\
{[-15.105]}\end{array}$ \\
\hline $\operatorname{IED}(H H)$ & - & - & $\begin{array}{r}-5.678^{* * *} \\
{[-7.190]} \\
\end{array}$ & - & - & - \\
\hline Shrlnd & $\begin{array}{r}5.167^{* * *} \\
{[7.697]} \\
\end{array}$ & $\begin{array}{r}9.498^{* * * *} \\
{[9.065]} \\
\end{array}$ & $\begin{array}{r}8.302^{* * *} \\
{[7.598]}\end{array}$ & $\begin{array}{r}9.441^{* * *} \\
{[9.007]} \\
\end{array}$ & $\begin{array}{r}12.026^{* * *} \\
{[8.272]}\end{array}$ & $\begin{array}{r}9.043^{* * *} \\
{[14.108]}\end{array}$ \\
\hline Sec & $\begin{array}{r}1.753^{* * *} \\
{[3.657]}\end{array}$ & $\begin{array}{r}3.502 * * * \\
{[4.529]} \\
\end{array}$ & $\begin{array}{c}1.869^{*} \\
{[2.375]}\end{array}$ & $\begin{array}{r}3.394^{* * * *} \\
{[4.369]} \\
\end{array}$ & $\begin{array}{r}3.049^{* *} \\
{[3.053]}\end{array}$ & $\begin{array}{r}3.360 * * * \\
{[7.279]}\end{array}$ \\
\hline Metro & $\begin{array}{r}1.331^{* * *} \\
{[3.763]}\end{array}$ & $\begin{array}{r}2.487 * * * \\
{[4.476]}\end{array}$ & $\begin{array}{r}3.481 * * * \\
{[6.431]}\end{array}$ & $\begin{array}{r}2.806^{* * *} \\
{[5.064]}\end{array}$ & $\begin{array}{l}2.92^{* * *} \\
{[4.028]}\end{array}$ & $\begin{array}{r}2.675^{* * *} \\
{[8.186]}\end{array}$ \\
\hline$N N E$ & $\begin{array}{r}-0.84^{* * *} \\
{[-3.875]}\end{array}$ & $\begin{array}{r}-1.138^{* * *} \\
{[-3.424]}\end{array}$ & $\begin{array}{r}-1.641^{* * *} \\
{[-5.073]}\end{array}$ & $\begin{array}{r}-1.286^{* * *} \\
{[-3.844]}\end{array}$ & - & $\begin{array}{r}-1.205^{* * * *} \\
{[-5.730]}\end{array}$ \\
\hline
\end{tabular}

Notes: *** $p<0.1 \%$; ** $p<1 \%$; ${ }^{*} p<5 \%$; t-stat in brackets.

Two other variables were also changed (models III and IV). In model III, the KI was replaced by the Herfindahl-Hirschman index $(\mathrm{HH})$ as the proxy for the industrial specialization of the regions. It intended to assess whether the effects found for the specialization or the diversification of regions with the KI remain with an alternative specialization index. In model IV, the proxy for University $R \& D$ was replaced by the number of full-time 
professors per inhabitant to verify the robustness of the results. Again, the results remained the same.

Finally, two additional regressions were estimated: one only for South and Southeast regions (model V) and another for all Brazilian micro-regions but for a longer period of time (model VI). The South and Southeast cohort is supported by the extensive innovation gaps in the northern portion of Brazil, which are evident in the previous LISA analysis and in the heterogeneity of the spatial dimensions of the regions. Finally, model VI includes five years of patents (2001-2005) and allows a guarantee that the results are not restricted to specific factors or to the short time frame of two years (2004-2005) but rather remain over a longer period. However, to accomplish this estimation, it is necessary to have another independent variable for the level of Industrial $R \& D$ because the original proxy is not available for periods before 2003. Therefore, although it is a weaker proxy, the share of engineers in the total employees at the regional level was used because data are available for the whole period.

Overall, results from these models confirm former results: positive and significant coefficients for industrial and academic R\&D; a significant and positive autoregressive term (WPatPC); and a negative and significant specialization index. Signs and significance of the controls remained the same; the only exception was the level of agglomeration (Agglom) which was not significant in two models (III and V).

\subsection{Agglomeration and diversification}

It is important to take a specific look at the results on the industrial structure of the regions. First, the main results show that diversified regions are more innovative than specialized ones. Second, agglomerated regions are positively related to innovation, which shows the role of the agglomeration of resources in the urban areas in fostering innovation.

Previous studies indicate that the degree of diversification is closely associated to agglomeration (Duranton and Puga, 2000). Therefore, it is relevant to consider in detail the cases in which diversification and agglomeration occur simultaneously, which can be accomplished by including a simple interaction between the variables in the model. Thus, the interaction would distinguish the effect of diversification and agglomera- 
tion together and the sole effect of both diversification and agglomeration. In order to link diversification and agglomeration, the specialization index was built in the opposite direction, by inverting the $\mathrm{KI}$ and multiplying it by -1 . Thus, this new indicator," $-\mathrm{KI}$ ", ranges from -2 to 0 , which means that the most specialized regions take the value closest to -2 and the most diverse closest to 0 . The estimation is presented in Table 4 .

Table 4 Regression results - Patents per capita $(\log )$

\begin{tabular}{lrr}
\hline & $-\mathbf{K I}$ & Interaction \\
\hline \multirow{2}{*}{ WPatPC } & $0.294^{* * *}$ & $0.275^{* * *}$ \\
\multirow{2}{*}{ R\&DInd } & {$[4.956]$} & {$[4.956]$} \\
\hline \multirow{2}{*}{ R\&DUniv } & $0.142^{* * *}$ & $0.152^{* * *}$ \\
& {$[3.874]$} & {$[4.287]$} \\
\hline \multirow{2}{*}{ Agglom } & $0.478^{* * *}$ & $0.472^{* * *}$ \\
& {$[6.354]$} & {$[6.251]$} \\
\hline \multirow{2}{*}{ KI } & $0.227^{* *}$ & 0.050 \\
& {$[2.608]$} & {$[0.478]$} \\
\hline \multirow{2}{*}{ KI*Agglom } & $3.083^{* * *}$ & 0.468 \\
\multirow{2}{*}{ Shrlnd } & {$[9.928]$} & {$[0.466]$} \\
\hline \multirow{2}{*}{ Sec } & - & $1.622^{* *}$ \\
& & {$[2.677]$} \\
\hline \multirow{2}{*}{ Metro } & $9.533^{* * *}$ & $9.531^{* * *}$ \\
\hline \multirow{2}{*}{$N$} & {$[9.240]$} & {$[9.257]$} \\
\hline
\end{tabular}

Notes: ${ }^{* *} p<0.1 \%$; ${ }^{* *} p<1 \%$; $p<5 \%$; t-stat in brackets.

Obviously, the inversion of KI causes a reversal of the sign of the specialization index, and other coefficients remain similar to the original model. However, the inclusion of the interaction term (-KI * Agglom) changes the results. The diversification and agglomeration per se are not significant, although they maintain their initial signs, and the interaction term is positive and significant, suggesting that the density of the regions and diversification have significant and positive effects on innovation only when they occur at the same time. 
This finding reduces the importance of diversification and agglomeration per se and reinforces the perception that Jacobian advantages are especially linked to major agglomerated and diversified centres (Storper and Venables, 2004). Thus, the occurrence of diversification and agglomeration in a region creates these special local conditions, which provide greater innovation performance.

\section{Conclusions}

Innovation depends on a wide range of factors. Several elements that can benefit from the innovation results must be considered when analysing this phenomenon from the regional point of view. For this reason, many studies have sought to explore how and why different local factors can allow better innovative performance.

To assess this topic, the empirical analysis in this paper involved estimating a model based on the Jaffe-Griliches KPF using a Spatial Autoregressive Tobit (SAR-Tobit) estimation. The adoption of a Spatial Tobit is justified by the large number of Brazilian micro-regions that did not register any patents in this period because it allows us to adequately address the observations of regions without patents. In this way, it is possible to obtain the estimated results without the potential downward bias that would occur with a sample censored to zero and to assess the spatial dynamics and the effects of interregional innovation spillovers.

The empirical results show that the local R\&D level is positively related to innovation in the region which points to the importance of local firms' research as a main component of regional innovation. Additionally, there is a positive association between university research and the number of patents per capita which corroborates several studies that report academic research as an important factor of local patenting.

With regard to local characteristics, the estimation results show that agglomeration and diversification imply a higher innovation corroborating the advantages of agglomeration are also important in the Brazilian case. Additionally, diverse regions tend to have higher numbers of patents, which is evidence of Jacobian advantages for innovation in Brazil.

An alternative estimation with an interaction term between density and diversity indicated that urban agglomeration and diversification are ben- 
eficial for innovation only when they occur at the same time. Therefore, agglomeration and diversification per se do not generate benefits for companies to innovate, but the combination of these two factors does. This result indicates that large, diversified urban centres generate significant benefits for innovation, supporting Storper and Venables's (2004) view that companies in locations with these characteristics have largely favourable conditions for innovation.

Regarding spatial effects, the autoregressive term indicated a positive effect of the proximity of particularly innovative regions. This finding points to the occurrence of interregional spillovers of innovative activity, indicating that companies in a particular region can benefit from effects of proximity to the innovations of a neighbouring locality.

In short, two main contributions derive from this work. First, spatial interregional spillovers are important drivers of regional innovation in Brazil reaffirming benefits for firms in locations near innovative regional poles. Second, this study corroborates the evidence that Jacobian externalities are beneficial for innovation since local industrial diversification and agglomeration are beneficial for local innovation.

Our results have some policy implications. First, they show the importance of private $R \& D$ levels not only for local innovation but also for the generation of spillovers towards neighbouring regions. Policies designed to foster the increase in private $\mathrm{R} \& \mathrm{D}$ expenditures can reinforce the positive regional effects of innovation. In addition, diverse and dense regions present a particularly positive dynamic for innovation, which suggests the opportunity for policy measures tailored to this industrial configuration. This result confirms the need to move away from a "one size-fits-all" policy approach to innovation.

Nevertheless, policy makers can develop measures to take advantage of the more favourable conditions for innovation offered by large diversified centres. The results show that local characteristics can play an important role in fostering regional innovation, namely, agglomeration and diversification. In this way, policies should comprise measures that strengthen the role of local characteristics by stimulating firms to benefit from the geographical concentration of innovative inputs. This implication is particularly important for developing countries, since their industrial $\mathrm{R} \& \mathrm{D}$ expenditures are weaker and scarcer than those in developed countries. Policies that aim to strengthen local factors could mobilize a set of local 
innovation efforts, such as local university research, to support private inhouse innovation efforts. At the same time, less specialized and densely populated regions need a different schedule of policy imbalance because these locations do not have the same favourable terms of densification and diversification for innovation; therefore, they depend on the formation of local skills and capabilities geared towards innovation.

Finally, for research agendas, this paper points to the relevance of further studies that deeply address the relation between agglomeration and diversification not only for innovation but also for productivity and economic growth.

\section{References}

ACS, Z. J.; AUDRETSCH, D. B.; FELDMAN, M. P. R \& D spillovers and recipient firm size. The Review of Economics and Statistics, p. 336-340, 1994.

ALBUQUERQUE, E. et al. A distribuição espacial da produção científica e tecnológica brasileira: uma descrição de estatísticas de produção local de patentes e artigos científicos. Revista Brasileira de Inovação, v. 1, n. 2 jul/dez, p. 225-251, 2009.

ANSELIN, L.; VARGA, A.; ACS, Z. Local geographic spillovers between university research and high technology innovations. Journal of urban economics, v. 42, n. 3, p. 422-448, 1997.

AUDRETSCH, D. B.; FELDMAN, M. P. R\&D spillovers and the geography of innovation and production. The American Economic Review, v. 86, n. 3, p. 630-640, 1996.

AUTANT-BERNARD, C.; LESAGE, J. P. Quantifying knowledge spillovers using spatial econometric models. Journal of Regional Science, v. 51, n. 3, p. 471-496, 2011.

BEAUDRY, C.; SCHIFFAUEROVA, A. Who's right, Marshall or Jacobs? The localization versus urbanization debate. Research Policy, v. 38, n. 2, p. 318-337, 2009.

CABRER-BORRAS, B.; SERRANO-DOMINGO, G.. Innovation and R\&D spillover effects in Spanish regions: A spatial approach. Research Policy, v. 36, n. 9, p. 1357-1371, 2007.

CAPELLO, R.; LENZI, C. Territorial patterns of innovation: a taxonomy of innovative regions in Europe. The Annals of Regional Science, v. 51, n. 1, p. 119-154, 2013.

CARLINO, G. A.; CHATTERJEE, S.; HUNT, R. M. Urban density and the rate of invention. Journal of Urban Economics, v. 61, n. 3, p. 389-419, 2007.

CARLINO, G.; KERR, W. R. Agglomeration and innovation. In: Handbook of regional and urban economics. Elsevier, p. 349-404, 2015.

CHAVES, C. V. et al. The contribution of universities and research institutes to Brazilian innovation system. Innovation and Development, v. 6, n. 1, p. 31-50, 2016.

CORSATEA, T. D.; JAYET, H.. Spatial patterns of innovation activities in France: market's role versus public research efforts. The Annals of Regional Science, v. 52, n. 3, p. 739-762, 2014. 
CRESCENZI, R.; RODRÍGUEZ-POSE, A.; STORPER, M.. The territorial dynamics of innovation: a Europe-United States comparative analysis. Journal of Economic Geography, v. 7, n. 6, p. 673-709, 2007.

CRESCENZI, Riccardo; RODRÍGUEZ-POSE, Andrés; STORPER, Michael. The territorial dynamics of innovation in China and India. Journal of Economic Geography, v. 12, n. 5, p. $1055-1085,2012$.

DE GROOT, H.; POOT, J.; SMIT, M. J. Which agglomeration externalities matter most and why?. Journal of Economic Surveys, v. 30, n. 4, p. 756-782, 2016.

DURANTON, G.; PUGA, D.. Diversity and specialisation in cities: why, where and when does it matter? Urban Studies, v. 37, n. 3, p. 533-555, 2000.

DURANTON, G.; PUGA, D. Nursery Cities: Urban Diversity, Process Innovation, and the Life Cycle of Products. The American Economic Review, Vol. 91, No. 5 (Dec., 2001), p. 14541477, 2001.

FELDMAN, M. P.; AUDRETSCH, D.B. Innovation in cities: Science-based diversity, specialization and localized competition. European economic review, v. 43, n. 2, p. 409-429, 1999.

FERNANDES, A.C. et al. Academy-industry links in Brazil: evidence about channels and benefits for firms and researchers. Science and Public Policy, v. 37, n. 7, p. 485-498, 2010.

FORNARI, V.C.B.; GOMES, R,; MORCEIRO, P. C. Atividades inovativas em indústrias de "baixa e média-baixa" tecnologias: um exame dos mecanismos de difusão da inovação. Nova Economia, v. 24, n. 1, p. 75-97, 2014.

FREITAS, Maria Viviana; GONÇALVES, Eduardo; MONTENEGRO, Rosa Livia Gonçalves. Desigualdade tecnológica, convergência espacial e transbordamentos: uma análise por estados brasileiros (1990-2001). Revista Brasileira de Estudos Regionais e Urbanos, v. 4, n. 2, p. 1-18, 2010.

FRITSCH, M.; SLAVTCHEV, V. Universities and innovation in space. Industry and Innovation, v. 14 , n. 2, p. 201-218, 2007.

FRITSCH, M.; SLAVTCHEV, V. How does industry specialization affect the efficiency of regional innovation systems?. The Annals of Regional Science, v. 45, n. 1, p. 87-108, 2010.

FISCHER, M. M.; VARGA, A.. Spatial knowledge spillovers and university research: Evidence from Austria. The Annals of Regional Science, v. 37, n. 2, p. 303-322, 2003.

GONÇALVES, E. O padrão espacial da atividade inovadora brasileira: uma análise exploratória. Estudos Econômicos (São Paulo), v. 37, n. 2, p. 405-433, 2007.

GONCALVES, E.; ALMEIDA, E.. Innovation and spatial knowledge spillovers: evidence from Brazilian patent data. Regional Studies, v. 43, n. 4, p. 513-528, 2009.

GONÇALVES, E.; FAJARDO, B.. A influência da proximidade tecnológica e geográfica sobre a inovação regional no Brasil. Revista Econômica Contemporânea, v. 15, n. 1, p. 112-142, 2011.

GONÇALVES, E.; RIBEIRO, D.; FREGUGLIA, R.S.. Skilled labor mobility and innovation: a study of Brazilian microregions. Pesquisa e Planejamento Econômico, v. 46, n. 2, 2016.

GREUNZ, L.. Geographically and technologically mediated knowledge spillovers between European regions. The Annals of Regional Science, v. 37, n. 4, p. 657-680, 2003.

GRILICHES, Z. Issues in assessing the contribution of research and development to produc- 
tivity growth. The Bell Journal of Economics, p. 92-116, 1979.

GRILICHES, Z. "Patent Statistics as Economic Indicators: A Survey", Journal of Economic Literature XXVIII, p. 1661-1707, 1990.

HENDERSON, J. V. Externalities and industrial development. Journal of Urban Economics, 42, p. 449-470, 1997.

HENDERSON, J. V. Marshall's scale economies. Journal of Urban Economics, 53 (1), 1-28, 2003.

JAFFE, A. B. Real effects of academic research. The American Economic Review, p. 957-970, 1989.

KANG, D.; DALL'ERBA, S. An Examination of the Role of Local and Distant Knowledge Spillovers on the US Regional Knowledge Creation. International Regional Science. 1-13. DOI: 10.1177/0160017615572888. 2015.

LESAGE, J.P.; PACE, R. K. Introduction to Spatial Econometrics. CRC Press, 2009.

LESAGE, J. P.; PACE, R. K. The biggest myth in spatial econometrics. Econometrics, v. 2, n. 4, p. 217-249, 2014.

MORENO, R.; PACI, R.; USAI, S. Spatial spillovers and innovation activity in European regions. Environment and Planning A, v. 37, n. 10, p. 1793-1812, 2005.

MONTENEGRO, Rosa Livia; GONÇALVES, Eduardo; ALMEIDA, Eduardo. Dinâmica espacial e temporal da inovação no estado de São Paulo: uma análise das externalidades de diversificação e especialização. Estudos Econômicos (São Paulo), v. 41, n. 4, p. 743-776, 2011.

NAGAOKA, S.; MOTOHASHI, K.; GOTO, A. Patent statistics as an innovation indicator. In: Handbook of the Economics of Innovation. North-Holland, 2010. p. 1083-1127.

OLIVEIRA, Priscila Medeiros de; GONÇALVES, Eduardo; ALMEIDA, Eduardo Simões de. Existe convergência de patenteamento no Brasil?. Revista Brasileira de Inovação, v. 15, n. 2, p. 335-364, 2016.

PACI, R.; MARROCU, E.; USAI, S. The complementary effects of proximity dimensions on knowledge spillovers. Spatial Economic Analysis, v. 9, n. 1, p. 9-30, 2014.

RODRIGUEZ, R.S.; GONÇALVES, E. Hierarquia e concentração na distribuição regional brasileira de invenções por tipos de tecnologias. Revista Brasileira de Inovação, v. 16, n. 2, p. 225-266, 2017.

SIMÕES, R.et al. A distribuição espacial da produção científica e tecnológica brasileira: uma descrição de estatísticas de produção local de patentes e artigos científicos. Revista Brasileira de Inovação, v. 1, n. 2, p. 225-251, 2002.

SOBRINHO, E.M.S.; AZZONI, C.R. Potencial inovativo da indústria nas regiões brasileiras. Revista Brasileira de Inovação, v. 15, n. 2, p. 275-304, 2016.

STORPER, M.; VENABLES, A. J. Buzz: face-to-face contact and the urban economy, Journal of Economic Geography, 4, 351-370, 2004.

SUZIGAN, Wilson et al. University and industry linkages in Brazil: some preliminary and descriptive results. Seoul Journal of Economics, v. 22, n. 4, p. 591, 2009.

YING, L.G. The shape of ideas production function in transition and developing economies: evidence from China. International Regional Science Review, v. 31, n. 2, p. 185-206, 2008. 


\section{About the authors}

Veneziano de Castro Araújo - veneziano.araujo@unifesp.br

Universidade Federal de São Paulo, Osasco, SP, Brazil - Departamento de Economia.

ORCID: https://orcid.org/0000-0003-0994-8327.

Renato Garcia - renatogarcia@eco.unicamp.br

Universidade Estadual de Campinas, Campinas, SP, Brazil - Instituto de Economia.

ORCID: https://orcid.org/0000-0001-9739-1658.

This work was supported by FAPESP - Fundação de Amparo a Pesquisa do Estado de São Paulo [2012/23.370-5; 14/175630; 15/50.044-0 and 16/04253-9]; and CNPq - Conselho Nacional de Desenvolvimento Científico e Tecnológico [Grant number 473.705/2013-3].

\section{About the article}

Submission received on November 3, 2017. Approved for publication on July 7, 2018. 


\section{APPENDIX}

Table A1 Global Moran I - patents/10.000 inhab. all micro-regions Brazil (2001-2005)

\begin{tabular}{lrrrrr}
\hline Year & Moran Index & t stat & Std deviation & Marginal prob. \\
\hline $\mathbf{2 0 0 5}$ & 0.3869 & 17.3 & 0.0224 & 0.000 \\
\hline $\mathbf{2 0 0 4}$ & 0.4136 & 18.4 & 0.0255 & 0.000 \\
\hline $\mathbf{2 0 0 3}$ & 0.4014 & 17.9 & 0.0224 & 0.000 \\
\hline $\mathbf{2 0 0 2}$ & 0.2885 & 13.5 & 0.0213 & 0.000 \\
\hline $\mathbf{2 0 0 1}$ & 0.3514 & 16.0 & 0.0220 & 0.000 \\
\hline
\end{tabular}

Table A2 Principal Component Analysis

\begin{tabular}{lrr|r|r}
\hline Component & Eigen value & Difference & Proportion & Cumulated \\
\hline Comp 1 & 1.76428 & 1.52857 & 0.8821 & 0.8018 \\
\hline Comp 2 & 0.235716 & 0 & 0.1179 & 0.9745 \\
\hline & & & \\
\hline Variable & Comp 1 & Comp 2 \\
\hline Graduate programs & & 0.7071 & 0.7071 \\
\hline Full-time professors & & 0.7071 & -0.7071 \\
\hline
\end{tabular}




\begin{tabular}{|c|c|c|c|}
\hline$n=1116$ & $\begin{array}{r}\text { 20-nearest } \\
(\mathrm{A}) \\
\end{array}$ & $\begin{array}{r}\text { Inverse distance } \\
\text { (B) }\end{array}$ & $\begin{array}{r}\text { Queen } \\
\text { (C) }\end{array}$ \\
\hline WPatPC & $\begin{array}{r}0.102^{* * *} \\
{[2.578]}\end{array}$ & $\begin{array}{r}0.281^{* * *} \\
{[4.995]}\end{array}$ & $\begin{array}{r}0.154^{* * *} \\
{[3.569]}\end{array}$ \\
\hline R\&DInd & $\begin{array}{r}0.153^{* * * *} \\
{[4.368]} \\
\end{array}$ & $\begin{array}{r}0.144^{* * *} \\
{[3.889]} \\
\end{array}$ & $\begin{array}{r}0.145^{* * *} \\
{[3.958]} \\
\end{array}$ \\
\hline R\&DUniv & $\begin{array}{r}0.492^{* * *} \\
{[6.534]}\end{array}$ & $\begin{array}{r}0.488^{* * * *} \\
{[6.417]} \\
\end{array}$ & $\begin{array}{r}0.506^{* * *} \\
{[6.620]}\end{array}$ \\
\hline Agglom & $\begin{array}{r}0.266^{* *} \\
{[3.115]}\end{array}$ & $\begin{array}{r}0.242^{* *} \\
{[2.819]} \\
\end{array}$ & $\begin{array}{r}0.256^{* *} \\
{[3.033]} \\
\end{array}$ \\
\hline$K I$ & $\begin{array}{l}-3.192^{* * *} \\
{[-10.629]}\end{array}$ & $\begin{array}{r}-3.189 * * * \\
{[-10.314]}\end{array}$ & $\begin{array}{l}-3.066^{* * *} \\
{[-10.083]}\end{array}$ \\
\hline Shrlnd & $\begin{array}{r}10.886^{* * *} \\
{[10.504]}\end{array}$ & $\begin{array}{r}9.599 * * * \\
{[9.195]}\end{array}$ & $\begin{array}{r}10.193^{* * *} \\
{[9.850]}\end{array}$ \\
\hline $\mathrm{Sec}$ & $\begin{array}{r}3.710^{* * *} \\
{[4.986]} \\
\end{array}$ & $\begin{array}{r}3.604^{* * *} \\
{[4.723]}\end{array}$ & $\begin{array}{r}3.578^{* * *} \\
{[4.671]} \\
\end{array}$ \\
\hline Metro & $\begin{array}{r}2.365^{* * *} \\
{[4.325]} \\
\end{array}$ & $\begin{array}{r}2.35^{* * * *} \\
{[4.232]} \\
\end{array}$ & $\begin{array}{r}2.381^{* * *} \\
{[4.311]}\end{array}$ \\
\hline NNE & $\begin{array}{r}-1.934^{* * *} \\
{[-6.156]}\end{array}$ & $\begin{array}{r}-1.183^{* * *} \\
{[-3.44]}\end{array}$ & $\begin{array}{r}-1.812^{* * *} \\
{[-5.880]}\end{array}$ \\
\hline
\end{tabular}

Notes: ${ }^{* *} p<0.1 \%$; ${ }^{* *} p<1 \%$; ${ }^{*} p<5 \%$; t-stat in brackets.

Table A4 Description of Variables - Additional variables.

\begin{tabular}{llr}
\hline Variable & Description & Source \\
\hline PatIndPC $t_{t}$ & Invention Patents Filed per 10.000 inhabitants in micro-region & INPI and IBGE \\
\hline PatnUnvPC & $\begin{array}{l}\text { Total Patents Filed excluding Academic Patents per 10.000 in- } \\
\text { habitants in micro-region }\end{array}$ & INPI and IBGE \\
\hline Eng & Industrial R\&D- Engineers per 10.000 workers in micro-region & RAIS \\
\hline Prof & University R\&D- Full-time Professors per 10.000 inhab & INEP and IBGE \\
\hline HH & $\begin{array}{l}\text { Herfindhal-Hirschman Index - employment CNAE 1.0 Manufac- } \\
\text { turing and Extractive Industries }\end{array}$ & RAIS \\
\hline
\end{tabular}


Table A5 Correlation Matrix

\begin{tabular}{lrr|r|r|r|r|r|r|r|r}
\hline & PatPC & R\&DInd & R\&DUniv & Agglom & Metro & Shrlnd & NNE & Sec & KI & HH \\
\hline PatPC & 1 & & & & & & & & & \\
\hline R\&DInd & 0.3272 & 1 & & & & & & & \\
\hline R\&DUniv & 0.3328 & 0.2137 & 1 & & & & & & \\
\hline Agglom & 0.4401 & 0.3467 & 0.3734 & 1 & & & & & \\
\hline Metro & 0.2300 & 0.2730 & 0.3242 & 0.5630 & 1 & & & & \\
\hline ShrInd & 0.3375 & 0.1736 & 0.0221 & 0.3809 & 0.0063 & 1 & & & \\
\hline NNE & -0.4578 & -0.2374 & -0.2085 & -0.4361 & -0.0711 & -0.3971 & 1 & & \\
\hline Sec & 0.3486 & 0.2895 & 0.1979 & 0.4088 & 0.1901 & 0.1938 & -0.3674 & 1 & \\
\hline KI & -0.3834 & -0.1982 & -0.2888 & -0.5742 & -0.2857 & -0.1267 & 0.4404 & -0.3921 & 1 \\
\hline HH & -0.2884 & -0.2242 & -0.2023 & -0.3800 & -0.1903 & -0.0559 & 0.3875 & -0.4662 & 0.7193 & 1 \\
\hline
\end{tabular}

